\author{
KS. STANISŁAW BIAŁY \\ Wydział Studiów nad Rodziną \\ Uniwersytetu Kardynała Stefana Wyszyńskiego w Warszawie
}

\title{
PRZEMIANY WIELOKULTUROWE A ZAKRES POJĘCIOWY PRZESTĘPSTWA ABORCJI: REFLEKSJE W ŚWIETLE KANONU 1398
}

Treść: Wstęp. - 1. Zmiany zjawiskowe dotyczące pojęcia i faktu aborcji. 2. Zastany stan doktrynalny: KPK i inne dokumenty Kościoła katolickiego. - 3. Wnioski do zastosowania.

\section{Wstęp}

Refleksje, co do aktualnych aspektów aksjologii obrony życia ludzkiego w zmieniającym się (wielokulturowym) świecie, chcemy zacząć od następującego założenia: Otóż jeśli ludzie wierzący w Boga, rozumiejąc konieczność obrony poczętego życia ludzkiego, (coraz częściej) oczekują od polityków konkretnych deklaracji, jako przyszłych decydentów w tej ważnej sprawie ${ }^{1}$, to powstaje pytanie, co rozumieją jedni i drudzy pod terminem „aborcja”, a szczególnie, jak określają jej zakres pojęciowy². Takie pytanie rodzi się wraz z zachodzącymi

\footnotetext{
${ }^{1}$ Portugalia: proliferzy żądają od polityków stanowiska wobec aborcji, https:// kair. ekai.pl/depesza/560598/show (24.10.2018); tamże: „Portugalska Federacja na rzecz Życia, grupująca sympatyków walki przeciwko prawu aborcyjnemu, wezwała rodzimych polityków do zaprezentowania „jasnego stanowiska” w kwestii ochrony życia nienarodzonych dzieci”.

${ }^{2}$ S. Warzeszak, Wokół początków życia ludzkiego, Pastores 1/74 (2017); https:// prasa. wiara.pl/doc/3745974.Wokol-poczatkow-zycia-czlowieka(12.03.2017); tamże: „Wciąż w rozmaitych kontekstach, debatach i w przestrzeni medialnej powraca sprawa ochrony życia poczętego. A jeśli mówi się o ochronie życia od poczęcia, to
} 
przemianami leksykalnymi, jak też zjawiskowymi, które dotykają konkretnych postaw ludzi, ich światopoglądu, etyki, religijności, moralności, zaangażowania społecznego itp. Biskupi Polscy mówią wprost o „zamieszaniu moralnym, które towarzyszy różnym problemom dotykającym początków życia ludzkiego"”. Nadto ważne jest, jak problem ten widzi prawo kanoniczne Kościoła katolickiego, które zmierza, aby integrować wierzących w Boga (w obrządku katolickim), ale też i wszystkich ludzi dobrej woli.

Chodzi o to, że jeśli kanoniści opisują to prawo jako zjawisko ontologiczne, społeczne, psychologiczne, moralne itp. (por. R. Sobański, Teoria prawa...), to wszystko to jest oczywiste przy założeniu pierwszoplanowej roli tegoż prawa w normatywnym opisie rzeczywistości Kościoła, a już szczególnie, jeśli mamy dobrze opisany zakres powinności etycznej. Aborcja tu jest tak dalece „trudnym i bolesnym” faktem, że dla adekwatnej oceny moralnej, jak i skonkretyzowanych postanowień $\mathrm{KPK}^{4}$, nie może być czymś, co jest pozostawione swobodnemu biegowi wydarzeń. Zatem kolejnym pytaniem jest, czy postępujące zmiany społeczne (tj. mentalnościowe, moralne, zjawiskowe itp.), adekwatnie szybko są uwzględniane w prawodawstwie kościelnym, powołanym, aby zabezpieczać normatywnie: etyczny i religijny (tj. duchowy) wymiar życia wspólnoty wierzących (por. KPK 1752: salus animarum suprema lex $)^{5}$. O takiej potrzebie pisał

powraca kwestia aborcji, jej dostępności i dopuszczalności przez prawo, a także procedury in vitro, będące de facto aborcją selektywną”.

${ }^{3}$ In vitro to „selektywna aborcja”, https://news.money.pl/artykul/in;vitro;to; selektywna; aborcja(9.04.2013); tamże: „Życie ludzkie ma zawsze taką samą wartość, a wszelkie wątpliwości co do istnienia człowieka zawsze należy rozstrzygać na korzyść życia. To stanowisko zawarte jest w ogłoszonym dziś w Warszawie dokumencie $O$ wyzwaniach bioetycznych, przed którymi stoi współczesny człowiek. Dokument został przyjęty przez biskupów na marcowym zebraniu plenarnym Konferencji Episkopatu Polski”.

${ }^{4}$ Kodeks Prawa Kanonicznego (KPK) 1983 wraz z jego późniejszymi zmianami: „ostatnie zmiany weszły w życie 1 października 2017 r.”

${ }^{5}$ J. Dyduch, Rola Kodeksu Prawa Kanonicznego 1983 w realizowaniu misji Kościoła, Prawo Kanoniczne 57 (2014) nr 1, s. 23; tamże: „KPK pomaga realizować tradycyjną zasadę: „Salus animarum suprema lex est” - Zbawienie dusz winno być 
następująco wspomniany już kanonista R. Sobański: „ «Kanonista wśród prawników jest oryginalny, ale nie może być zacofany». Należy więc zdecydowanie popierać postulat prawnej poprawności prawa kościelnego, który służy nie tylko technicznej czy zewnętrznej stronie prawa, ale i jego istocie czy też głębi. Precyzja prawna służy bowiem jakości teologicznej tego prawa"6. Czy więc KPK (kanon 1398) nakładający ekskomunikę za przerwanie ciąży (tj. np. za usunięcie embrionu $\mathrm{z}$ ustroju matki), a nie mówiący o zabijaniu ludzkich embrionów podczas procedur in vitro lub klonowania (tj. np. na etapie poczęcia życia ludzkiego), wystarczająco opisuje zakres problemu, jakim jest „aborcja”, tzn. konkretyzując go ze strony materialnej i formalnej. Czy (tym samym) określenie: „ekskomunika za aborcję” - stosunkowo często obecne w literaturze przedmiotu - nie jest zwrotem (jakoś) wprowadzającym zwykłego czytelnika w błąd.

\section{Zmiany zjawiskowe dotyczące pojęcia i faktu aborcji}

Dla lepszego zobrazowania zarysowanego powyżej problemu, wydaje się, iż najlepiej będzie, jeśli sięgniemy do konkretnych przykładów, które wymagają adekwatnej prawniczej interpretacji. Innymi słowy chodzi o to, że korzystając z literatury przedmiotu, w tym z medialnego przekazu, łatwo możemy natknąć się na „głośne” nowe i stare przypadki, które domagają się analogicznej konstatacji, co do ich sposobu notyfikacji istniejącego stanu rzeczy. Chodzi o taką epistemologię, gdzie pod kątem przedmiotowym pojęcie „aborcji” jest utożsamiane z samym aktem „przerwania ciąży”, i która: „mówiąc o karze ekskomuniki za aborcję”, (w domyśle, tzn. poprzez wymieniony kontekst), przypisuje ją czynom nie karanym w ten sposób

najwyższym prawem w Kościele” (por. kan. 1752 KPK)”; por. R. SobAŃsKI, „Salus animarum" jako cel prawa kanonicznego. Wszczęta przez Jana XXIII reforma KPK w świetle dyskusji o celu prawa kościelnego, w: W kierunku prawdy, Warszawa 1976, s. 201-217.

${ }^{6}$ R. SobAŃski, Nauki podstawowe prawa kościelnego, Teologia prawa kościelnego, t. 2: Warszawa 2001, s. 160; zobacz. P. Kroczek, Teoria prawa kościelnego w optyce ks. Remigiusza. Sobańskiego, w: Wkład ks. R Sobańskiego w rozwój kanonistyki, red. T, Gałkowski, Warszawa - Kraków 2014, s. 69-85. 
przez doktrynę Kościoła katolickiego ${ }^{7}$. Tymczasem z dokładniejszej analizy nauczania Kościoła wynika, że (w sensie ontologicznym i etyczno-moralnym) pojęcie „aborcji” jest przedmiotowo znacznie szersze niż „przerwanie ciąży”, (tj. niż sztuczne poronienie: łac. abortus provocatus). Niestety „dzis”" mamy nagminne zjawisko leksykalnego sugerowania czegoś innego. Terminy „aborcja” i „przerwanie ciąży" są używane zamiennie ${ }^{8}$ albo pod różnymi synonimami, jak: „procedura selekcyjna”, „forma eugenizmu”, „selekcja embrionów”, "dzieciobójstwo" itp. Spotykamy to nie tylko w tzw. świeckich publikatorach, co w artykułach naukowych'; np. w pracach dyplomowych pisanych na uniwersytetach katolickich ${ }^{10}$. Można tu także wskazać na publicystyczne opracowania ${ }^{11}$, jednakże są one szeroko dostępne,

${ }^{7}$ M. BıаєKowsKa, Aborcja: kobieta, grzech, kara, Przewodnik Katolicki 17 (2016); https://opoka.org.pl/biblioteka/P/PS/pk201617_aborcja.html(22.04.2016); tamże: „Ekskomunika za aborcję wynika z potrzeby uświadomienia, jak wielkim złem jest aborcja, ponieważ nie ma wciąż takiego powszechnego przekonania. Przypomniał o tym papież Franciszek"; por. Katechizm Kościoła Katolickiego (KKK), Poznań 1994, nr 2270-2272: który cytując KPK ściśle mówi o ekskomunice za akt przerwania ciąży, a nie za akt aborcji.

${ }^{8}$ Abp Gądecki o aborcji: występek szczególnie godny potępienia, https://www. wprost.pl/kraj/430433/Abp-Gadecki-o-aborcji(23.12.2013); tamże: „Wśród wszystkich przestępstw przeciwko życiu, jakie człowiek może popełnić, przerywanie ciąży ma cechy, które czynią z niego występek szczególnie poważny i godny potępienia - mówił podczas pasterki w poznańskiej katedrze abp Stanisław Gądecki”.

${ }^{9}$ J. A. Kultys, Aborcja: problem religijno-filozoficzno-społeczny, Słupskie Studia Filozoficzne 5 (2015), s. 95-116; T. ZADY KOWICZ, Początek ludzkiego życia - z perspektywy nauczania Kościoła katolickiego. Próba określenia oraz konsekwencje etyczne, Roczniki Teologii Katolickiej 1/VIII (2014), s. 247; tamże: „Skrajną formą zamachu na życie u jego początków jest aborcja. Niszcząc już istniejące życie, bezpośrednio łamie ona Boże przykazanie „nie zabijaj”. Jako dobrowolne zabójstwo niewinnej osoby ludzkiej jest zawsze poważnym nieładem moralnym, które Kościół katolicki - po zaistnieniu skutku - sankcjonuje karą ekskomuniki wiążącej mocą samego prawa".

${ }^{10} \mathrm{~K}$. KHARITONOWA, Wsparcie udzielone kobietom po stracie dziecka w wyniku aborcji $w$ duszpasterstwie winnica Racheli, praca magisterska UKSW, Warszawa 2018.

${ }^{11}$ Por. Porzadkowanie in vitro. Wywiad z posłem, Idziemy 46 (2018), s. 4. 
zatem: opiniotwórcze, jak np. Fronda.pl. (tamże: „Ekskomunika po aborcji - co mówi prawo kanoniczne") ${ }^{12}$.

Za emblematyczny można uznać wywiad przeprowadzony przez M. Pabis, pt. „Popieranie in vitro to grzech ciężki”. Znajdziemy tam następującą redaktorską opinię wykluczającą zabijanie embrionów ludzkich z zakresu pojęciowego aborcji: „Prawo kanoniczne nic nie mówi na temat in vitro. W prasie cytowana jest np. taka opinia: «Nie można prosto powiedzieć, że niszczenie embrionów w procedurze in vitro, które jest oczywiście zabijaniem, ale nie jest aborcją, podpada pod kary kościelne, jakie pociąga za sobą aborcja»" "13. Chodzi o to, że udzielający wywiadu hierarcha (bezpośrednio) nie przeczy tak postawionej sprawie, chociaż w kwestii odpowiedzialności karnej precyzuje, że niszczenie embrionów „jest grzechem ciężkim, nie wolno więc sprawcy przystępować do komunii św. aż do nawrócenia się". Natomiast cytuje on dokument Episkopatu, który mówi o „ekskomunice za akt aborcji” bez (jak się wydaje) koniecznego dookreślenia, o jaki konkretnie akt zabójstwa występującego pod pojęciem „aborcja” niewinnej istoty ludzkiej będzie prawu chodzić, tak, aby mogła zapaść taka kara, jaką jest ekskomunika. Tamże: „Nikt nie może się publicznie opowiadać za tzw. aborcją, która jest jednym z największych przestępstw obłożonych ekskomuniką wiążącą mocą samego prawa"14.

Tymczasem (w sensie doktrynalnym) pojęcie „aborcja” obejmuje swoim przedmiotowym zakresem występek „przerwania ciąży”, ale także wszelkie akty uśmiercania embrionów ludzkich powołanych do życia pozaustrojowo (np. w probówce, tj. in vitro) ${ }^{15}$. Zresztą w społecznej świadomości przebija się coraz częściej właśnie takie stanowisko. Przykładem mogą być artykuły, jak: „In vitro to selektywna

\footnotetext{
${ }^{12}$ K. Cipion, Ekskomunika po aborcji - co mówi prawo kanoniczne, http:// www. fronda.pl/a/ekskomunika-po-aborcji-co-mowi-prawo-kanoniczne,79454. $\operatorname{html}(3 / 10 / 2016)$.

${ }^{13}$ Popieranie in vitro to grzech cięzki, http://www.radiomaryja.pl/bez-kategorii/ popieranie-in-vitro-to-grzech-ciezki/(25.05.2010).

${ }_{14}$ Tamże.

${ }^{15}$ Por. KKK 2270-2275.
} 
aborcja” lub „In vitro jak aborcja”16 itp. Co więcej, wraz z dalszym tzw. „rozwojem społeczeństw”, mogą pojawiać się inne tego typu semantyczne zjawiska, spełniające niestety eufemistyczną funkcję. Zatem (jednakowoż) oczekiwana byłaby tu precyzja, co do adekwatnego i nie wprowadzającego w wątpliwość ustalenia zakresu pojęciowego czynu, jakim jest „aborcja”. W myśl tradycyjnej doktryny moralnej Kościoła, za zmianami zachodzącymi w społeczeństwie powinna podążać stosownie szybko norma ustawodawcza. W ten sposób Kościół katolicki chce wyrazić swą szczególną wrażliwość w zakresie obrony życia ludzkiego, szczególnie tego, które jest niewinne i bezbronne. Dobrym punktem odniesienia, (tj., że zachowania takie mają swoje należne miejsce), jest decyzja papieża Franciszka z 8 grudnia 2015 r. Zdecydował on o przyspieszeniu procedur stwierdzających nieważność małżeństwa ${ }^{17}$, a tym samym bardziej dopasował prawo kanoniczne do potrzeb wynikających z naszych czasów. Analogicznie: jeśli chcemy pojęcie „aborcji” w sensie zakresowym ująć precyzyjnie, to należy zauważyć, że: gdy „przerwanie ciąży” jest sztucznym poronieniem (łac. abortus provocatus), czyli „aborcją” ustrojową, to już pojęcie „aborcja” nie będzie tylko tym oto jednym i tym samym faktem, tj. "przerwaniem ciąży”: istnieje bowiem abortio pozaustrojowe. Podobnie: kara ekskomuniki nakładana jest za „przerwanie ciąży”, a nie za „aborcję”, którą będzie np. niszczenie embrionów w procedurach in vitro lub klonowania (także tego, które nazywane jest terapeutycznym). Jeszcze inną kwestią, jaka się w tym kontekście pojawia, jest sprawa zakresu czasowego „aborcji”. Jeśli jest nią (tradycyjnie rzecz

\footnotetext{
${ }^{16}$ W. LeWANDOWSKa, „In vitro” jak aborcja, Niedziela 2 (2008); tamże: „ Metoda zapłodnienia in vitro jest rodzajem wyrafinowanej aborcji, gdyż przy każdej próbie w tej metodzie giną liczne embriony - alarmuje Kościół. Tymczasem rząd mówił o refundowaniu tych zabiegów z budżetu państwa”.

${ }^{17}$ A. PustuŁka, Papież upraszcza procedury unieważnienia małżeństwa. Wprowadza szybkq ścieżkę, https://dziennikzachodni.pl/papiez-upraszcza-procedury(14.09.2015); tamże: „Papież Franciszek chce uprościć te procedury poprzez wprowadzenie tylko jednej instancji. Poza tym w szczególnych przypadkach proces ma trwać 45 dni. Wtedy jedynym sędzią w takim procesie będzie biskup diecezjalny".
} 
ujmując) zabicie niewinnej istoty ludzkiej w okresie: począwszy od poczęcia a skończywszy na urodzeniu, to dziś i tu rodzą się semantyczne wątpliwości w związku z pojawieniem się terminologii: „aborcja po urodzeniu", tzn. jak wydaje się - eufemistycznej, kamuflującej opisywaną rzeczywistość.

Niniejszym w kwestii prezentacji aktualnych semantycznych i moralnych „ewolucji i nastawień”, w przedmiocie materialnym występku „aborcji”, można przedstawić następujące cytacje: „Lekarze powinni mieć prawo do zabijania noworodka - takie szokujace stanowisko opublikowało dwoje naukowców ze znanych na świecie uczelni. Według nich pozbawić dziecka życia można nie tylko wtedy, gdy urodzi sie ono np. niepełnosprawne. Również wtedy, gdy rodzice nie sq w stanie zapewnić dziecku opieki lub po prostu go nie chca. Nazwali to aborcja po urodzeniu"18. „Argumenty na rzecz życia przeciwko dzieciobójstwu «nie sa przekonujacce» $i$ «nie moga pokazywać dzieciobójstwa jako niemoralnego»"'19. J. Räsänen jest tylko jednym $z$ wielu bioetyków, który przyznaje rodzicom niepetnosprawnych dzieci prawo do „aborcji po urodzeniu”. (...) „Bioetycy za wprowadzeniem aborcji po urodzeniu” (...) Australijscy bioetycy wzbudzili międzynarodowy skandal po tym, jak argumentowali prawo do «aborcji po porodzie», zwłaszcza w przypadku dzieci niepełnosprawnych, gdzie takie dzieci moga być nie do zniesienia ciężarem dla rodziny i społeczeństwa jako całości”n.

\footnotetext{
${ }^{18}$ R. Kowalik, Aborcja po urodzeniu - szokujacy pomysł naukowców, http://wiadomosci. gazeta.pl/wiadomosci/1,114873,11268597,Aborcja_po_urodzeniu(1.03.2003); tamże: „W sukurs atakowanym zewsząd naukowcom przyszedł prof. Julian Savulescu, dyrektor oksfordzkiego centrum zajmującego się etyką medyczną i wydawca «Journal of Medical Ethics». Uważa on, że ostra reakcja na pomysł Minervy i Giubiliniego jest próbą kneblowania akademickiej dyskusji”.

${ }^{19}$ Bioetycy za wprowadzeniem aborcji po urodzeniu, https://medianarodowe.com/ bioetycy-za-wprowadzeniem-aborcji-po-urodzeniu(14.10.2018)..

${ }^{20}$ Tamże.
} 


\section{Zastany stan doktrynalny: KPK i inne dokumenty Kościoła katolickiego}

Jeśli do synonimów „aborcji” zaliczamy takie określenia jak: sztuczne poronienie, przerwanie ciąży, usunięcie ciąży, spędzenie płodu, zabieg, łyżeczkowanie, czyszczenie itp.; a „dla części środowisk takim synonimem jest także zabicie dziecka w okresie życia prenatalnego" ${ }^{21}$, to wydaje się, że stanowisko dotyczące zabicia istoty ludzkiej (tj. dziecka) jest tym, które nawiązuje (w szczególności) do nauki papieża Piusa XII i Jana Pawła II, a których nauczanie uwypukla encyklika Evangelium vitae nr 62. Znajdujemy tam zdanie: „Pius XII potępił wszelką aborcję bezpośrednią, to znaczy każdy akt, który zmierza wprost do zabicia jeszcze nie narodzonego życia ludzkiego, «niezależnie od tego, czy zabójstwo stanowi cel sam w sobie, czy też jest tylko środkiem do celu»". Podobne znaczenie posiada zamieszczona w tym to dokumencie cytacja Soboru Watykańskiego II, który w niniejszej kwestii wyraził się dwubiegunowo, tj. że „spędzanie płodu, jak i dzieciobójstwo są okropnymi przestępstwami”. Kolejnym ważnym, w niniejszej kwestii, jest punkt 63 Evangelium vitae, który mówi, że: „Ocena moralna przerywania ciąży dotyczy także nowych form zabiegów dokonywanych na embrionach ludzkich, które chociaż zmierzają do celów z natury swojej godziwych, prowadzą nieuchronnie do zabicia embrionów". Domyślamy się, że chodzi tu o zabiegi występujące w procedurach in vitro lub klonowania (w tym, jak mniemamy, klonowania przy użyciu komórek macierzystych). Chodzi o to, że ocena moralna, o której mówi papież Jana Paweł II, nigdy nie jest (i nie może być) oderwana od stanu faktycznego, tj. od tego, czy i kiedy mamy do czynienia z zaistnieniem występku, który rozumiemy pod pojęciem „aborcja”2

Także ważkie (dla nas) znaczenie ma to, co stwierdziła w r. 1998 w instrukcji Donum vitae, Kongregacja Nauki Wiary, a co (w obliczu powyższego) nie może być traktowane li tylko w odniesieniu do

\footnotetext{
${ }^{21}$ Uzupetnienie do Wielkiej ilustrowanej encyklopedii powszechnej Wydawnictwa „Gutenberga”, Warszawa 1996, s. 22-24.

${ }^{22}$ Jan PaWeŁ II, Encyklika Evangelium vitae (EV) 63.
} 
kwestii poczęcia naturalnego (tj. ustrojowego), a w konsekwencji li tylko do przerwania życia będącego w ustroju kobiety, czyli do tzw. „przerwania ciąży”. I tak dokument ten zauważa: „owoc przekazywania życia ludzkiego [czyli ludzki embrion] od pierwszej chwili swego istnienia, a więc od utworzenia się zygoty, wymaga bezwarunkowego szacunku, który moralnie należy się każdej istocie ludzkiej [...]. Istota ludzka powinna być szanowana i traktowana jako osoba od chwili swojego poczęcia i należy jej przyznać wszystkie prawa należne osobie łącznie z prawem do życia"23. Chodzi o to, że wniosek, jaki można postawić z niniejszej cytacji, może być tylko jeden: Jeśli zniszczenie embrionu ludzkiego (niezależnie gdzie on by się znajdował) jest zabójstwem istoty ludzkiej, tj. człowieka, to takie rozumienie wypełnia znamiona, które bezpośrednio dotyczą desygnatu nazwy, jaką jest "aborcja"24.

Podobnie Karta Praw Rodziny potwierdza tę samą zasadę i to samo rozumienie, mówiąc iż: „Życie ludzkie, od samego poczęcia, bezwzględnie winno być otoczone troską i szacunkiem"25. Mamy tu echo nauczania, jakie znajdujemy już w Deklaracji o przerywaniu ciąży: Quaestio de abortu procurato z roku 1974, które mówi: „Najnowsza genetyka bardzo jasno potwierdza to wszystko, co zawsze było oczywiste, niezależnie od dyskusji nad momentem animacji. Wykazała mianowicie, że istota żyjąca ma już od pierwszej chwili stałą strukturę czyli kod genetyczny: jest człowiekiem i to człowiekiem niepodzielnym, jako jednostka, wyposażonym we wszystkie właściwe sobie cechy. Od momentu zapłodnienia rozpoczyna się cudowny bieg każdego życia człowieka, którego jednak wszystkie wielkie zdolności wymagają czasu na właściwe uporządkowanie i przygotowanie do działania" 26 .

Jednakże, chyba najbardziej klarowne określenie, tj. najbardziej rozwiewające wątpliwości, co do zakresu omawianych pojęć

\footnotetext{
${ }^{23}$ Kongregacja Doktryny Wiary, Instrukcja Donum vitae.

${ }^{24}$ Tamże.

${ }^{25}$ Stolica Apostolska, Karta Praw Rodziny, Roma 1983.

${ }^{26}$ Kongregacja Doktryny Wiary, Deklaracja Qaestio de abortu procurato, nr 13.
} 
przedstawia instrukcja Dignitas personae nr 21 i 22. Znajdujemy tam stwierdzenie: „Z punktu widzenia etycznego redukcja embrionów jest zamierzoną aborcją selektywną. Jest to bowiem rozmyślne i bezpośrednie zniszczenie jednej lub wielu niewinnych istot ludzkich w początkowej fazie ich istnienia, i jako takie stanowi zawsze poważny nieporządek moralny". (...) "Diagnoza przedimplantacyjna - zawsze wiążąca się ze sztucznym zapłodnieniem, już samym w sobie w istocie niegodziwym - ma na celu faktycznie jakościową selekcję embrionów wraz z ich niszczeniem, która jawi się jako wczesne działanie aborcyjne. Tak więc diagnoza przedimplantacyjna jest wyrazem tej mentalności eugenicznej, «która dopuszcza selektywne przerywanie ciąży»" ${ }^{27}$.

Warto niniejszym dodać, że KPK (w kanonie 1398) nie używa pojęcia „aborcja” 28 , ale mówi o „przerwaniu ciąży”, podobnie jak KKK 2270-2272. Absolutnie nie bez znaczenia jest tak zastosowana nomenklatura, szczególnie, że ustawodawca za taki konkretny występek wyznacza karę ekskomuniki, której etyczny wymiar wiąże się z okrucieństwem dzieciobójstwa „pod sercem matki”. Domniemywać należy, że niniejszy tak ważny normatywny akt został w KPK skonstruowany celowo w taki właśnie sposób. Brzmi on bowiem jasno: „kto powoduje przerwanie ciąży, po zaistnieniu skutku, podlega ekskomunice wiążącej mocą samego prawa”. Ustawodawca chciał karać za ten konkretny czyn, a nie za każdy inny, który dotyczy zabójstwa nienarodzonej istoty ludzkiej.

Także Episkopat Polski, podkreślając, że Kościół katolicki czuje się w obowiązku bronić życia od początku aż do naturalnej śmierci,

\footnotetext{
${ }^{27}$ Kongregacja Doktryny Wiary, Instrukcja Dignitas personae nr 21 i 22; por. Ustawa z dnia 25 czerwca 2015 r. o leczeniu niepłodności, D.U. 2015 poz. 1087; art. 26; tamże: „Stosowanie preimplantacyjnej diagnostyki genetycznej w ramach procedury medycznie wspomaganej prokreacji jest dozwolone wyłącznie ze wskazań medycznych i poprzedza się tę diagnostykę poradnictwem genetycznym w ramach poradnictwa medycznego, o którym mowa w art. 5 ust. 1 pkt 1 . Preimplantacyjna diagnostyka genetyczna jest wykonywana w medycznym laboratorium diagnostycznym".

${ }^{28}$ Kodeks Prawa Kanonicznego (KPK) promulgowany 25 stycznia 1983 r.
} 
w dokumencie $O$ wyzwaniach bioetycznych, przed którymi stoi wspótczesny człowiek, jednoznacznie odnosi się do procedury poczęcia pozaustrojowego. „ «W wyniku tej metody embriony podlegają selektywnej aborcji - mówi przewodniczący Zespołu Ekspertów Konferencji Episkopatu Polski do spraw Bioetycznych, arcybiskup Henryk Hoser»" ${ }^{29}$. Zatem założyć można lub nawet należy, iż mówiąc „aborcja", hierarcha ma na myśli niszczenie życia ludzkiego poprzez usunięcie embrionu już zagnieżdżonego w ustroju matki, ale też fakt, że często są one niszczone jeszcze wcześniej, tj., przed transferem do łona, np. w wyniku niekorzystnej dla nich tzw. „diagnozy przedimplantacyjnej" Do takiego założenia (bowiem) upoważnia doktrynalne sformułowanie „wyrafinowanej aborcji” zastosowane odnośnie in vitro przez Radę ds. Rodziny KEP w liście do parlamentarzystów z 8 grudnia $2007 \mathrm{r}^{30}$.

Tym samym, jeśli w szerokiej literaturze bioetycznej, prawniczej, etycznej czy wręcz teologicznej, znajdujemy określenie: „ekskomunika za dokonanie aborcji”; a) powołujące się na prawo kanoniczne ${ }^{31}$;

${ }^{29}$ In vitro to „selektywna aborcja”, https://news.money.pl/artykul/in;vitro;to; selektywna; aborcja,242,0,1284850.html(9.04.2013).

${ }^{30}$ List Rady Konferencji Episkopatu Polski ds. Rodziny do posłów i senatorów 8 grudnia 2007 r., http://info.wiara.pl/doc/171775.List-Rady-ds-Rodziny-do-parlamentarzystow-na-temat-in-vitro (9.12.2007); tamże: „Pragniemy podzielić się naszą troską o małżeństwa i rodziny w kontekście ostatnich wypowiedzi Przedstawicieli Rządu RP na temat sztucznych zapłodnień in vitro. W nawiązaniu do tych wypowiedzi Rada ds. Rodziny pragnie przypomnieć nauczanie Stolicy Apostolskiej, a zwłaszcza Ojca Świętego Jana Pawła II, dotyczące tej kwestii. Po pierwsze - przy każdej próbie w tej metodzie giną liczne embriony - jest to rodzaj wyrafinowanej aborcji. Po drugie - każde dziecko ma prawo zrodzić się z miłosnego aktu małżeńskiego jego rodziców. I po trzecie - dziecko nie jest rzeczą i nawet przyszli rodzice nie mogą powiedzieć, że mają do niego prawo, zwłaszcza, że to prawo jest zawsze okupione śmiercią jego braci i sióstr".

${ }^{31}$ K. CipIor, Ekskomunika po aborcji - co mówi prawo kanoniczne, art. cyt.; tamże: „Osoba, która zaciągnęła karę ekskomuniki za dokonanie przestępstwa aborcji, samodzielnie lub jako integralny wspólnik czynu przestępczego, może prosić kapłana z okazji jego sakramentalnego posługiwania o pojednanie z Bogiem i wspólnotą Kościoła”; por. Ekskomunika za aborcję, http://www. bosko.pl/zycie/ Ekskomunika-za-aborcje.html. 
b) bez dokonania specyfikacji semantycznej ${ }^{32}$, to wydaje się, że taka sytuacja pojęciowa może być opisana jako mało precyzyjna. Wymaga ona $\mathrm{z}$ powodu na poważny przedmiot czynu (zabicie istoty ludzkiej) oraz $\mathrm{z}$ uwagi na związaną $\mathrm{z}$ nim bardzo surową karę ekskomuniki, zapadającej latae sententiae, adekwatnego doprecyzowania. Powstaje jednak pytanie: gdzie i w jakiej formie. Czy mogłoby to być dokonane w uaktualnionym KPK albo w Konwencji o Prawach Rodziny, o którą walczy Instytut na Rzecz Kultury Prawnej Ordo Iuris? ${ }^{33}$.

\section{Wnioski do zastosowania}

Pytanie o jasny wymiar terminologiczny, doktrynalny, leksykalny, epistemologiczny, zjawiskowy, moralny itp., w którym żyją dzisiaj społeczeństwa, jest także pytaniem o przejrzystość nauki Chrystusowej (ujętej w normy, przepisy, i kanony), w jej dotarciu, jako zbawcze przesłanie ewangeliczne, do każdego człowieka dobrej woli. Jest to pytanie o tyle ważne, że problem, jakim jest społeczny kontekst wyznawców katolicyzmu, którzy dzisiaj żyją w środowiskach wielokulturowych i wielowyznaniowych (ma to miejsce także w Polsce), znalazł się w centrum obrad na Synodzie Biskupów nt. „Młodzież, wiara i rozeznawanie powołania”: tj. 17 października $2018 \mathrm{r}^{34}$. Niniejszym zauważyć możemy, patrząc choćby tylko z czysto eklezjalnej perspektywy na ten ważki problem, iż warto, aby została zachowana semantyczna poprawność tak ważnych terminów, jakimi są: „aborcja”

\footnotetext{
${ }^{32}$ Por. E. Sztafrowski, Podręcznik prawa Kanonicznego, t. IV, Warszawa 1986, s. 364; tamże: „Ekskomunika wiążąca mocą samego prawa (latae sententiae) jest karą za przestępstwo aborcji. Kan. 1324 KPK podaje następujące okoliczności: jeżeli sprawca działa bez pełnej poczytalności, był pozbawiony pełnego używania rozumu, wola jego była ograniczona na skutek poważnego wzburzenia uczuciowego (jeżeli nie było ono wywołane dobrowolnie lub świadomie podtrzymywane), jeżeli sprawca był małoletni i ukończył szesnasty rok życia”.

${ }^{33}$ Konwencja o Prawach Rodziny - międzynarodowa gwarancja w obronie rodzin, https://ordoiuris.pl/dzialalnosc-miedzynarodowa/konwencja-o -prawach-rodziny-mie (15.06.2018).

${ }^{34}$ Wielokulturowość $i$ wielowyznaniowość to tematy sesji synodalnej 17 października, https://episkopat.pl/wielokulturowosc-i-wielowyznaniowosc -to-tematy-dzisiejszej-sesji-synodalnej-17-pazdziernika/(17.10.2018).
} 
i „przerywanie ciąży”. Tj. tak uszczegółowiona, aby mogła uwzględnić najnowsze technologie, ocenę bioetyczną, ale także zmiany mentalnościowe, jakie obecnie następują $\mathrm{w}$ rozumieniu tych problemów. Chodzi o to, że takie określenia i synonimy, jak: „ekskomunika za aborcje”, , ,aborcja jako niszczenie embrionów”, „, in vitro jako aborcja selektywna”, „aborcja po urodzeniu”, „diagnostyka przedimplantacyjna jako wczesne działanie aborcyjne”, „tzw. aborcja” itp. - przez wiernych różnie mogą być interpretowanie pod względem prawnym i etycznym (por. EV 58) ${ }^{35}$. Tym samym, ze względu na powagę problematyki (por. KPK - 1752: salus animarum suprema lex), właściwym pytaniem będzie już nie tyle sama troska o sens takiej potrzeby, ale o to, kto i kiedy miałby to uczynić. To znaczy: w jakiej skutecznej formie należałoby to zrobić dla ostatecznego rozwiania: a) narosłych z czasem eufemistycznych wątpliwości; b) zaciemnianej (socjotechniką) konkretnej rzeczywistości moralnej.

Stwierdzenie „ekskomunika za aborcję", nie jest wystarczająco precyzyjne, choćby ze względu na nakładaną karę ekskomuniki (latae sentantiae), i (jako takie) zawsze wymaga doprecyzowania. Z nadzieja doktrynalną (niniejszym) można patrzeć na działalność Instytutu na rzecz Kultury Prawnej Ordo Iuris, który, odnośnie troski o rodzinę i jej prawa, następująco określił swoją kolejną bardzo ważną inicjatywę o znaczeniu międzynarodowym (tzn. ogólno-kościelnym): „Każdego dnia prawnicy Ordo Iuris niosą skuteczną pomoc rodzinom i dzieciom krzywdzonym przez złe prawo. Dostrzegając, że główne źródło patologii, jakie zwalczamy na salach sądowych, leży na poziomie międzynarodowym, przygotowaliśmy Konwencję o Prawach Rodziny.

\footnotetext{
${ }^{35}$ EV 58; tamże: „Właśnie w przypadku przerywania ciąży można się dziś często spotkać z dwuznacznymi określeniami, jak na przykład „zabieg”, które zmierzają do ukrycia jego prawdziwej natury i złagodzenia jego ciężaru w świadomości opinii publicznej. Być może, samo to zjawisko językowe jest już objawem niepokoju nurtującego sumienia. Jednak żadne słowo nie jest w stanie zmienić rzeczywistości: przerwanie ciąży jest - niezależnie od tego, w jaki sposób zostaje dokonane świadomym i bezpośrednim zabójstwem istoty ludzkiej w początkowym stadium jej życia, obejmującym okres między poczęciem a narodzeniem”.
} 
To realna przeciwwaga dla genderowej «konwencji przemocowej» i wynikających z niej norm, które uderzają w małżeństwo i rodzinę" ${ }^{\text {"36 }}$.

Jeśli uznamy, iż prawne zdefiniowanie pojęcia „aborcja”, ujęte ściśle w całym swoim przedmiotowym zakresie, byłoby rzeczą jak najbardziej pożądaną, to w dalszej kolejności chodziłoby o to, aby właściwe instytucje, w ramach swojej działalności - np. na rzecz zatwierdzenia i promulgacji Konwencji o Prawach Rodziny - zechciały uwzględnić niniejszy postulat. Mogłoby się to dokonać, po odbyciu właściwych sobie konsultacji z adekwatnymi eksponentami Kościoła, podjętych w duchu troski o rodzinę i jej prawa ${ }^{37}$. Chodzi o to, że jak nie można utożsamiać zakresu pojęciowego występku „aborcji” z zakresem występku „przerwania ciąży”, tak samo nie można (w przestrzeni prawnej i bioetycznej) godzić się na „semantyczne eufemizmy” (tj. nadużycia) typu: „aborcja po urodzeniu”. Trzeba zawsze nazywać taką rzecz po imieniu; jest to bowiem dzieciobójstwo, mające swą już dobrze utwierdzoną (negatywną) konotację moralną i religijną, której nie należy zmieniać.

\footnotetext{
${ }^{36}$ Ordo Iuris - brawo po raz kolejny!, https://www.fronda.pl/forum/ordo-iuris-brawo-po-raz-kolejny,90711.html(22.10.2018); por. Przepisy dotyczace aborcji $w$ Polsce, http://matkaprawnik. pl/przepisy-dotyczace-aborcji-w-polsce/(18.02.2018); zobacz: „przepisy dotyczące okoliczności, w których możliwa jest aborcja jako przerwanie ciąży, na terenie RP, znajdują się w Ustawie o planowaniu rodziny, ochronie płodu ludzkiego i warunkach dopuszczalności przerwania ciąży, z dnia 7 stycznia 1993 r.”. Właśnie - i tu mamy przykład, że jeśli nawet ustawa reguluje kwestię przerwania ciąży, a nie dokonania aborcji, to w tych licznych komentarzach, artykułach, tytułach itp., pojęcia te pojawiają się zamiennie.

${ }^{37}$ Spotkał się Zespół Ekspertów KEP ds. Bioetycznych, https://episkopat.pl/spotkal-sie-zespol-ekspertow-kep-ds-bioetycznych(9.11.2018); tamże: „Zespół podjął też dyskusję na temat toczącej się obecnie debaty na temat ustawy dotyczącej kwestii in vitro. Gremium przygląda się temu zagadnieniu z punktu widzenia numeru 73 encykliki św. Jana Pawła II «Evangelium vitae». Zespół Ekspertów KEP ds. Bioetycznych jest głosem doradczym Konferencji Episkopatu Polski w zakresie kwestii bioetycznych. Do zakresu jego działań należą: monitorowanie procesów legislacyjnych i wyrażanie opinii Kościoła na tematy bioetyczne, głos w dyskusji w sferze publicznej na ten temat, np. w formie oświadczeń bądź konferencji prasowych".
} 
Odwołanie się do działalności Instytutu Ordo Iuris, jest (ze strony autora) wyrazem głębokiego szacunku dla jego dorobku i różnych inicjatyw, ale i troski, aby słowa, choćby te, niżej cytowanie (nomen omen) z jego internetowej strony, miały łatwo zrozumiały dla współczesnego człowieka swój prawniczy i etyczny sens: „Sąd Rejonowy w Oławie opowiedział się za prawem do mówienia prawdy o aborcji oraz wolnością słowa, odwołując się do międzynarodowych i konstytucyjnych standardów. Pro-lifer umieścił w miejscu publicznym plakat prezentujący dziecko zabite w wyniku aborcji. Swoim postępowaniem miał rzekomo dopuścić się wybryku nieobyczajnego. Celem działania mężczyzny było opowiedzenie się za prawem do życia oraz pokazanie, czym jest aborcja" 38 .

\section{Multicultural transformations and the significance of terms concerning abortion: reflections in the light of canon 1398}

The author asks what we understand today under such terms as "abortion" and "termination of pregnancy", especially as Church legislature (CIC can. 1398) punishes the perpetrator of the act of killing innocent human life, located under "the mother's heart", with an excommunication latae sententiae. He argues that the semantic changes that are taking place today in connection with the development of biotechnology, but also with the cultural development of societies, demand a more deepened examination of this issue. He comes to the conclusion, analyzing the literature of the subject, including doctrinal documents of the Catholic Church, that although in present-day colloquial speech (but not only) there exists, an ethically dangerous identification of the concept of "abortion" with the concept of "termination of pregnancy" - in the official teaching of the Church we have clarity about the significance of these terms. However, the author calls for the doctrinal specification of this issue to be carried out, preferably as soon as possible, in order to reassure accuracy and avoid the euphemistic social engineering techniques of some circles operating in this ethical field (cfr. EV 58).

\footnotetext{
${ }^{38}$ Kolejny sąd potwierdził prawo do mówienia prawdy o aborcji, https://ordoiuris.pl/ ochrona-zycia/kolejny-sad-potwierdzil-prawo-do-mowienia-prawdy-o (18.10.2018).
} 
SŁOWA KLUCzowe: aborcja; przerwanie ciąży; doktryna Kościoła katolickiego; semantyczna poprawność; zakres pojęciowy; manipulacje; teoria prawa kanonicznego

KEYWORDS: abortion; termination of pregnancy; doctrine of the Catholic Church; semantic correctness; conceptual scope; manipulations; theory of canon law.

\section{Nota o Autorze:}

Ks. DR HAB. STANisŁaw Biaky, PROF. UKSW - profesor nadzwyczajny przy Katedrze Antropologii i Bioetyki na Wydziale Studiów nad Rodziną. 